\title{
IODINATION OF VEGETABLE OIL AS A METHOD FOR CORRECTING IODINE DEFICIENCY
}

\author{
Rodica STURZA \\ Technical University of Moldova, MD 2004, 168, Stefan cel Mare, Chisinau, Moldova \\ sturzar@yahoo.com, tel/fax: (3732-2) 31-91-45, (3732-2) 31-91-76
}

\begin{abstract}
The aim of this work is the study made for obtaining iodized oil that would satisfy the requirements in iodine for human body. The sunflower oil is a product with the most important value, thus the production of oil fortified with iodine would be a cheap and accessible option. These studies indicate that lipids present an important vehicle for the fortification with iodine. Eradication of the iodine deficiency may be realized not only by injection of the iodinated oil, but also by its use as an ingredient for the formulation of different food compositions. This method, complementary with the iodinated salt, would allow the increase of the efficiency of the prophylactic undertaken measures, because is based on the use of vegetal material - sunflower oil; it is cost-efficient and does not require substantial investments.
\end{abstract}

Keywords: iodine deficiency, food fortification, iodinated sunflower oil.

\section{INTRODUCTION}

\section{THE PROBLEM OF THE IODINE DEFICIENCY IN REPUBLIC OF MOLDOVA AND POSSIBILITY OF ERADICATION}

The iodine is an essential microelement necessary for the synthesis of the thyroid hormones [1]. Its importance, particularly for the development period, consists in the fact that the thyroid hormones have a capital role in the processes of growth, differentiation and maturation of the numerous cell tissues, especially for the bony and central nervous system tissue.

A malnutrition contribution in iodine would have as consequences the adulteration of the function of thyroid gland but also a direct impact concerning the physical and mental development of a person. The above pyramid (Figure 1) illustrates the fact that the visible effects of IDD (cretinism) account for only as much as $10 \%$ of the ramifications. At least $90 \%$ of IDD consequences remain hidden [2].

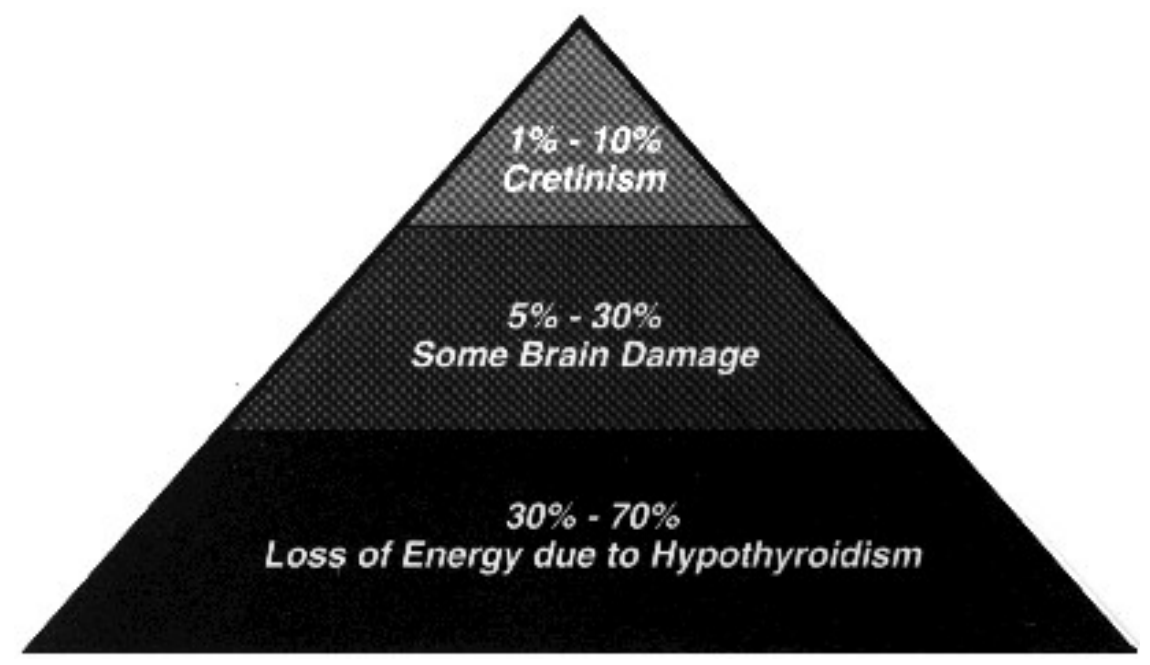

Figure 1. Iodine Deficiency Disorders (IDD) problem pyramid [2]

The normal contribution constitutes $150 \mu \mathrm{g} /$ day for children over 10 years and for adults and for children under 10 years constitutes $40-120 \mu \mathrm{g} / \mathrm{day}$. The supplementation of the ration with $25-50 \mu \mathrm{g} / \mathrm{day}$ in the period of pregnancy and lactation is necessary with a view to prevent the endemic cretinism $[6,7]$.

In the last 10-15 years the incidence of iodine deficiency disorders (endemic goiter) increased by 8-10 times [3]. The number of children and teen-agers at which the endemic hyperplasia of the thyroid gland is manifested is 33$47 \%$, and $2,8-5,7 \%$ of them have endemic goiter that is manifested by the appearance of visible knots, while 1,5-4,2\% suffers from hyperthyroidism [3,4]. The main cause of this phenomenon consists in the fact that the environment of Republic Moldova is characterized by a reduced values of the iodine content:4,5-5,3mg/kg soil, $40 \mathrm{mg} / 1$ water and $0,03-$ $0,22 \mathrm{mg} / \mathrm{kg}$ of vegetation, on a dry content of substances. The content of the urinary iodine for children $(7,84 \mu \mathrm{g}$ iodine $/ 100 \mathrm{dL}$ ) is the lowest from the European countries [5]. In order to eliminate the iodine deficiency disorders, the government of Republic of Moldova adopted a National Program by the year 2004 (decision nr. 46) [8]. 
However, the situation did not evolve too much in this direction. A recent estimation of the situation in the Republic of Moldova, based on official statistics, the reports of some experts-nutritionists and studies realized by international organs (UNICEF, WHO) pointed out the presence of palpable goiter for $\approx 36,7 \%$ children with the age between 8 and 10 years, and for the adult population the endemic goiter prevails at $\approx 40 \%$ of women in the period of begetting children [5]. There is an alarming growth of cases of disorders of thyroid gland cancer which is strongly connected with the accident from Chernobyl, according to the estimation of some experts. Only 32\% of families consume adequate iodinated salt, because it has a low storage period, after what it loses its curable quality [3, 4, 5]. It is obvious that the nutritional problems affect not only the health of certain groups of population, but also bring enormous harms to the economy of the country and to its socio-human potential, because:

- Iodine deficiency in the prenatal period and for children at early age decreases its Intelligence Quotient (IQ) with 5-13 points [9,10].

- Causes the mental retardation, which affects $9-9,6 \%$ of children of 5-12 years old $[11,12]$.

- The combined deficiency in iodine, iron and vitamin A decreases the economical performances of the country with more than $5 \%$ [13].

The specific strategies used in the developed countries in order to eliminate the nutritional deficiencies, can be classified in three main groups $[14,15,16]$ :

- The improvement of food practice;

- The supplementation of population groups of risk with tablets that contain necessary micronutrients;

- The fortification of large consumption food with micronutrients.

The application of the strategy of nourishment diversification in Republic Moldova is confronting a lot of problems: the precarious economical situation and the small wages of the majority of families, the high cost of the products that have a big content of hemic iron, iodine, calcium (beef, sea fish, milk products); traditional diets, which includes mainly products of vegetal origin with a high content of antinutrients (phytates, tannins, oxalates) which contribute to unavailability of the micronutrients.

The supplementation of population groups of risk with tablets that contain necessary micronutrients puts the problem of costs and logic. And also, this way represents a passive approach, which can't ensure some steps at national level, but can have only a strict temporary character and limited in time.

There are more opinions that the food fortification with micronutrients is an efficient method for the improvement of the statute in micronutrients of the population on a long term [7].

Once developed, food fortification is an inexpensive and durable method. An effective program of food fortification requires efforts of cooperation between Government, food industry and consumers.

The only way for food fortification, used nowadays in Republic of Moldova is iodination of salt. Iodinated salt constitutes traditionally the most applied method, because of the accessibility and because it is largely consumed by the local population. According to the investigation [5], the contribution of iodine from salt is yet insufficient. This depends on more facts: the consumption of salt varies from $2 \mathrm{~g}$ /day to $10-12 \mathrm{~g} / \mathrm{day}$, being lowest for children and elderly persons. The technology of iodination of salt (iodide, iodate ); the concentration of iodine $(10-15 \mathrm{mg} / \mathrm{kgsalt})$, as well the integral and partial utilization of iodinated salt, bring about considerable fluctuations in the contribution of iodine proceeded in this way. A deficiency of this method constitutes also the instability of iodine in salt.

Thus, the elaboration and implementation of some fortification technologies of widely consumed products, which will ensure a sufficient intake and bioavailability of micronutrients is extremely actual. A special role in this field play the technologies based on the use of natural local resources, because these are cost-efficient, there is no need to modify the structure of the traditional products and does not require considerable capital investments.

\section{THE PROPHYLAXIS AND TREATMENT OF THE IODINE DEFICIENCY}

Individually, the long term administration of iodine or thyroid hormones seams to be very efficient for the reduction the incidence of the iodine deficiency related diseases. For severe cases chirurgical treatment may be applied. But these interventions are expensive and may not be applied for all individuals. The most recommended way is the prophylaxis through the optimization of the iodine intake. This is recommended in the case when the urinary iodine excretion is less then $10 \mu \mathrm{g} / \mathrm{day}$, or when the incidence of the endemic goiter is higher than $10 \%$. Iodine may be administered either as iodinated salt or as iodinated oil.

In the salt the iodine is usually added as potassium or sodium iodide or iodate. Iodate is less stable, and is recommended for the regions with high humidity. In practice, this way of prophylaxis raises many important issues. First, it is about the variability of the iodine content, which may be between $4.3-14.1 \mathrm{mg} / \mathrm{kg}$ for the same product depending on the method and shelf life.

Another major problem is the iodination of the salt meant for home consumption, while the salt used in food industry it is not iodinated. Finally, the contribution of the salt is about 6-10 g/day for women and 10-12 g/day for men. Considering these values, it was set that a contribution of $15 \mathrm{mg}$ iodine $/ \mathrm{kg}$ salt is not sufficient to ensure an intake of $150 \mu \mathrm{g}$ iodine/day. In fact, the iodinated salt intake is estimated to be $2.2 \mathrm{~g}$ /day for adults, part of it being evaporated during cooking process. Thus, the real intake of iodinated salt is estimated to be $1.6 \mathrm{~g} /$ day. However, this is not accepted by any legislation of any country. 
Finally, a series of other problems, such as quality, cost, preservation regularity diminishes considerably the food iodine intake. From this point of view, in the regions with moderate and severe iodine deficiency the iodine prophylaxis is made by administration of the iodinated oil, usually injectable. The injection of the iodinated oil, which contains $475 \mathrm{mg}$ iodine $/ \mathrm{ml}$ provides a high amount of iodine which is slowly absorbed, depending on the human body's requirements. For 0-6 old children $0.2-0.4 \mathrm{ml}$ can be administered, and for 6-45 years old persons $1-2 \mathrm{ml}(475-950 \mathrm{mg}$ iodine), which would cover the human body requirements for about 3-5 years. These strategies are indicated especially for women during fertile period to prevent neonatal hypothyroid.

However, these drastic strategies may not be applied without a legal insurance which is essential. Over intake of the iodinated salt may lead to the administration of an excess of sodium ions, which is extremely inauspicious. Increased iodine intake, accomplished through the injection of the iodinated oil increases the incidence of the thyreotoxicoses, especially for individuals over 45 years old and for individuals with knotted endemic goiter.

The severances of the consequences of the iodine deficiency, as well as above mentioned factors makes this pathology very specific. The prophylaxis of the iodine deficiency, despite of the relatively simple strategies suggested, does not achieve proposed goals.

Thus, the decrease of the consequences related to an insufficient iodine intake may be achieved not solely through one method applied for all population, but through the application of a fortification strategy of different foodstuffs consumed by different population categories. These should be complementary with the iodinated salt, thus total intake should not overtake the daily recommended amount, so that this will not lead to any hyperthyroid status, which is manifested by anxiety and weight loss. In fact, the tolerance limit of the human body to the iodine excess is significant $-1 \mathrm{~g}$ / day (actually this value is the base of the administration of the injectable iodinated oil), but an overdose that should be taken into account is over $250 \mu \mathrm{g} / \mathrm{day}$.

Iodine, being a liposoluble element, its administration in products with a lipid origins represents a remarkable interest. First, this would allow the easy incorporation of the iodine in the food products. Secondly, the daily intake of lipids being limited, would allow an easy regulation of the iodine consumption, this being complementary with that from the iodinated salt and other products.

The problem is the establishment of some iodination principles of the lipids and of the incorporation of these ones into the food products. Therefore, the aim of the present work is to evaluate ways of incorporation of the iodine in its molecular state in the vegetal lipids - sunflower oil, and the study of the physico-chemical properties of the iodinated oil during storage and the technological transformation which might take place.

Sunflower oil being a widely consumed product for the population from Republic of Moldova, the fortification with iodine would be a considerable supplement (40-50 $\mu \mathrm{g}$ /day), which associated with the iodine intake from the iodinated salt, would eradicate the iodine deficiency.

\section{RESULTS AND DISCUSSIONS}

The physico-chemical properties of the lipids, which have a enormous importance for the food technology are determined by the chemical composition and their structure. The sunflower oil is part of the vegetal oils group and has a high content of mono- and poliunsaturated fatty acids [20] and is characterized by a high unsaturation degree, which means by a high number of sites capable to fix molecular iodine. Therefore, saturated fatty acids constitute just 11.3$11.6 \%$, iodine indices of the oil varying from 119 to 135 . Generally, unsaturated fatty acids from the vegetal oils are situated in the position 2 of the glycerin molecule. Linoleic acid, which is most abundant in this oil is mainly situated in this position. Oleic acid is situated in position 1, and saturated fatty acids in position 3 (fig. 2):

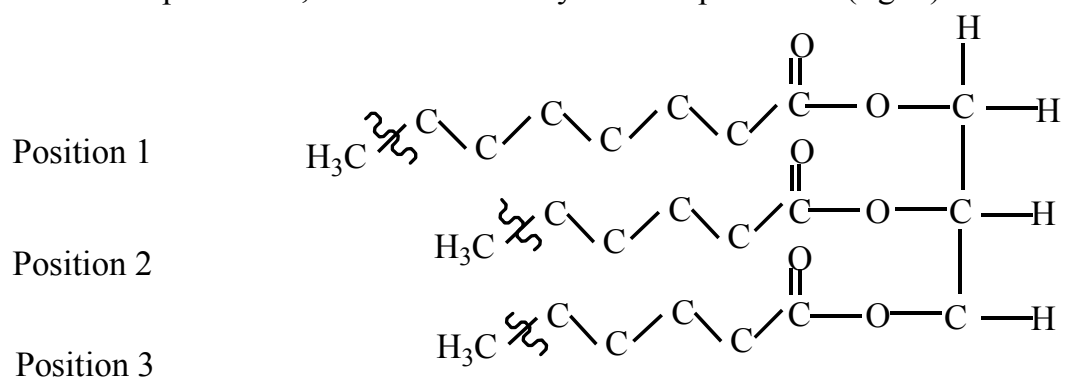

Figure 2. Fatty acids positioning in the trigliceride molecule

This positioning, as well as the „fourchette” shape specific for triglicerides facilitates the molecular iodine attack and its clamping in the position 2, mostly occupied by the linoleic acid (fig. 3). 
<smiles>[CH2]CCC(=O)OC(COC(=O)CC)COC(=O)CCC</smiles>

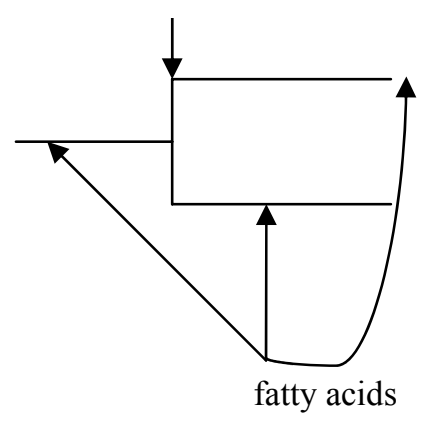

Figure 3. Shape « fourchette » of a trigliceride molecule

Lipids are susceptible to different degradation reactions, which may lead to the premature spoilage of the food products. These are:

- Hydrolytic oxidation;

- Oxidative oxidation.

During hydrolytic rancidity, triglicerides degraded and an liberation of fatty acids take place, thus the acidity of the lipid increases. During oxidative rancidity the spoilage take place as a result of the attack on the double bonds by the $\mathrm{O}_{2}$ from the air. The reaction is accelerated by light and temperature, the presence of the metallic and enzymatic catalyses.

These processes may be evaluated using different quality indices for lipids, which characterize the status of the lipid.

\section{The study of the composition and quality indices of the iodinated sunflower oil}

In order the evaluate the influence of the administration of iodine in the sunflower oil, main quality indices of the oil were studied, which were compared with the standards for the product.

It was found out, that the iodine indices does not varies greatly; even for the sample with the highest iodine amount $(1000 \mu \mathrm{g} / \mathrm{ml})$ its value does not overtake the highest allowable amount. This proves that the administrated iodine does not bind to the double bond through covalent bonds.

Refraction indices varies insignificantly, which disputes the presence of the free iodine in the samples with that contain $1-100 \mu \mathrm{g} / \mathrm{ml}$ iodine. Only for the samples with $1000 \mu \mathrm{g} / \mathrm{ml}$ iodine the presence of the free iodine could be certified.

Physico-chemical indices of the iodinated oil are indicated in table 1.

Table 1. Physical-chemical properties of the iodinated oil

\begin{tabular}{|c|c|c|c|c|c|c|}
\hline \multirow{2}{*}{ Physico-chemical indices } & \multirow{2}{*}{$\begin{array}{l}\text { Reference } \\
\text { sample }\end{array}$} & \multicolumn{4}{|c|}{ Iodinated oil, $\mu \mathrm{g} / \mathrm{ml}$} & \multirow{2}{*}{$\begin{array}{l}\text { Maximum } \\
\text { allowed }\end{array}$} \\
\hline & & 1 & 10 & 100 & 1000 & \\
\hline Iodine indice & $134 \pm 1$ & $131 \pm 1$ & $130 \pm 2$ & $129 \pm 1$ & $127 \pm 2$ & $119-135$ \\
\hline $\begin{array}{l}\text { Refraction indice } \\
\left(20^{\circ} \mathrm{C}\right)\end{array}$ & $\begin{array}{c}1,474 \pm \\
0,001\end{array}$ & $\begin{array}{c}1,475 \pm \\
0,002\end{array}$ & $\begin{array}{c}1,476 \pm \\
0,001\end{array}$ & $\begin{array}{c}1,476 \pm \\
0,001\end{array}$ & $\begin{array}{c}1,479 \pm \\
0,002\end{array}$ & $1,472-1,476$ \\
\hline $\begin{array}{l}\text { Saponification indice, } \\
\mathrm{mg} \mathrm{KOH/g} \text { oil }\end{array}$ & $193 \pm 3$ & $191 \pm 2$ & $195 \pm 2$ & $196 \pm 1$ & $198 \pm 2$ & $181-198$ \\
\hline $\begin{array}{l}\text { Free fatty acids content, } \\
\% \text { oleic acid }\end{array}$ & $\begin{array}{c}0,245 \pm \\
0,005\end{array}$ & $\begin{array}{r}0,245 \pm \\
0,004\end{array}$ & $\begin{array}{c}0,275 \pm \\
0,003\end{array}$ & $\begin{array}{c}0,285 \pm \\
0,003\end{array}$ & $\begin{array}{c}0,360 \pm \\
0,005\end{array}$ & Maximum 0,4 \\
\hline Peroxid indice, méq/kg, & $10,0 \pm 0,2$ & $8,9 \pm 0,1$ & $9,8 \pm 0,2$ & $10,9 \pm 0,1$ & $23,0 \pm 0,3$ & Maximum 12 \\
\hline $\begin{array}{l}\text { Humidity and the volatile } \\
\text { substance } \%, \text { maximum }\end{array}$ & $\begin{array}{c}0,100 \pm \\
0,005\end{array}$ & $\begin{array}{l}0,055 \pm \\
0,005\end{array}$ & $\begin{array}{l}0,068 \pm \\
0,005\end{array}$ & $\begin{array}{l}0,100 \pm \\
0,005\end{array}$ & $\begin{array}{l}0,098 \pm \\
0,005\end{array}$ & 0,100 \\
\hline
\end{tabular}

It is well known that halogens are capable to saturate double bonds present in the unsaturated lipids. For active halogens, such us fluoride and chloride, the addition to the double bonds takes place according to the mechanism that involves the formation of an ion type halonium as a result of the nucleophile bimolecular substitution [20]: 
<smiles>[R]C([R])C</smiles><smiles>[R]C1[Y4]([R])([H])[C@@]1([R2])CC</smiles><smiles>[X]C([R])([2H])C([R2])([2H])[2H]</smiles>

The iodine addition through this mechanism does not take place, because the energy necessary to activate the reaction is very high. However, the electrophile attack of the iodine is frequently used for the mixed halogens. Thus, the measurement of the iodine indice is realized through the reactive Wijs - ICl. The addition of the iodine chloride takes place rapidly and constitutes an effective way to establish the unsaturation degree of the triglicerides.

As well, the value of the iodine indice considerably depends on the position of the double bond comparing with the carboyile group -COO-. Thus, experimental values of the iodine indice, obtained depending on the positioning of the double bond in the oleic acid molecule vary considerably depending on the distance between the double bond and carboxyle group (table 2):

Table 2. Experimental values of the iodine indices obtained for different oleic acid isomers*

\begin{tabular}{|c|c|c|}
\hline Double bond positioning & Theoretical values & Experimental values \\
\hline$-2=3-$ & 89,7 & 9,04 \\
\hline$-3=4-$ & 89,7 & 16,27 \\
\hline$-4=5-$ & 89,7 & 26,96 \\
\hline$-6=7-$ & 89,7 & 89,7 \\
\hline$*[20]$ & \multicolumn{2}{|c}{} \\
\hline
\end{tabular}

It was established that, while the number of the carbon atoms between the carboxyl group -COO- and the double bond increases, the probability that the addition of the halogen reaction will take place decraeses [20]. Since fatty acids, present in the sunflower oil have double bonds situated in the position $-9=10$ - and $-11=12$ - (linoleic acid), the probability that the iodine addition in these conditions will take place is very low.

It is obvious that, during iodination of the sunflower oil the iodine addition cannot take place. The activity of the double bonds is weaker more they are away from the carboxyl group. The growth of the carbon atoms in the acid chain decreases the activity of the double bonds and reduces the saturation speed.

The amount of the saturated fatty acids, monounsaturated and poliunsatured in the reference sample and after the iodination of the oil was determined by gaz chromatography with a flame ionization detector. These analyses were anticipated by the esterification of the samples (methanolize).

Therefore, it was certainly established that the amount of main fatty acids in the sunflower oil (oleic and linoleic acid) does not vary significantly. As well the amount of the respective saturated acids does not vary greately (table 3). Only the concentration of the monounsaturated acids vary, which are present in inessential amounts: palmitoleic acid (C 16:1) and gatoleic acid (C 20:1).

Table 3. The amount (\%)of the fatty acids in the iodinated sunflower oil

\begin{tabular}{|c|c|c|c|c|c|c|c|}
\hline \multirow[b]{2}{*}{ No. } & \multirow[b]{2}{*}{ Sample } & \multirow{2}{*}{$\begin{array}{l}\text { Iodine } \\
\text { concentr. } \\
\mu \mathrm{g} / \mathrm{ml}\end{array}$} & \multicolumn{5}{|c|}{ Concentration, \% } \\
\hline & & & $\begin{array}{c}\mathrm{C}_{16: 0} \\
\text { (Palmitic) }\end{array}$ & $\begin{array}{r}\mathrm{C}_{18: 0} \\
\text { (Stearic) }\end{array}$ & $\begin{array}{c}\mathrm{C}_{18: 1} \\
\text { (Oleic) }\end{array}$ & $\begin{array}{r}\mathrm{C}_{18: 2} \\
\text { (Linoleic) }\end{array}$ & $\begin{array}{l}\mathrm{C}_{20: 0} \\
\text { (Arahidic) }\end{array}$ \\
\hline 1 & Reference & - & $6,46 \pm 0,03$ & $3,37 \pm 0,03$ & $22,37 \pm 0,05$ & $66,40 \pm 0,18$ & $0,46 \pm 0,05$ \\
\hline 2 & $1: 1000$ & 1 & $6,42 \pm 0,02$ & $3,38 \pm 0,05$ & $22,37 \pm 0,05$ & $66,70 \pm 0,20$ & $0,56 \pm 0,03$ \\
\hline 3 & $1: 100$ & 10 & $6,42 \pm 0,02$ & $3,37 \pm 0,04$ & $22,29 \pm 0,05$ & $66,57 \pm 0,15$ & $0,75 \pm 0,05$ \\
\hline 4 & $1: 10$ & 100 & $6,42 \pm 0,02$ & $3,37 \pm 0,05$ & $22,23 \pm 0,04$ & $66,61 \pm 0,18$ & $0,63 \pm 0,06$ \\
\hline 5 & $1: 1$ & 1000 & $6,41 \pm 0,03$ & $3,33 \pm 0,05$ & $22,29 \pm 0,03$ & $66,77 \pm 0,22$ & $0,67 \pm 0,07$ \\
\hline
\end{tabular}

According to the data obtained during the experiments, following was established:

- Incorporation of the molecular iodine in the sunflower oil does not lead to the bursting of the double bond and the addition of the iodine according to the nucleophile bimolecular substitution mechanism that is characteristic to other halogens. This was established certainly by the estimation of the composition of fatty acids in the triglycerides from the oil for the iodine concentration ranging from 1 to $1000 \mu \mathrm{g} / \mathrm{ml}$. As well verification of the unsaturation degree of the product (iodine indices) confirms the invariability of the number of double bonds from the trigliceride molecule.

- In the infrared region of the electromagnetic field the lipid absorbs radiant energy at 2 specific waveleghts in the middle infrared $-\lambda_{\max }=3.45 \mu \mathrm{m}$ and $5.73 \mu \mathrm{m}$; and 2 specific wavelengths in the near infrared $-1724 \mathrm{~cm}^{-1}$ and 1230 $\mathrm{cm}^{-1}$. The vibration of the characteristic groups of the lipids for these wavelengths causes an important variation of the optical density, which is correlative directly with the lipid amount having these groups.

In order to evaluate the influence of the administration of the molecular iodine in the sunflower oil the infrared field of the iodinated sunflower has been analyzed (IR) in comparison with the non iodinated sunflower oil. 
For the non iodinated oil as well as for the iodinated one ( 1 to $1000 \mu \mathrm{g} / \mathrm{ml})$ the spectrum in both specific wavelengths for lipids was analyzed: $1724 \mathrm{~cm}^{-1}$ for the carbonyl group $\mathrm{C}=\mathrm{O}$ of the unsaturated acids and $1230 \mathrm{~cm}^{-1}$ (resonance strip) with two harmonious strips at $1110 \mathrm{~cm}^{-1}$ and $1163 \mathrm{~cm}^{-1}$ specific for the C-O group. It was established, that the intensity of the absorption strips of the light for these specific wavelengths does not vary as a matter of fact regardless to the iodine concentration and correspond to the literature data for the sunflower oil.

- The presence of the molecular free iodine was certified just for the high concentrations - at $1000 \mu \mathrm{g} / \mathrm{ml}$, and for concentrations $1-100 \mu \mathrm{g} / \mathrm{ml}$ free iodine is absent in the solution. This is also confirmed by the evolution of the peroxide indices, which remains constant for iodine concentrations $1-100 \mu \mathrm{g} / \mathrm{ml}$.

Iodine occupies a special place and is different from the other halogens due to its capacity to form complex compounds while delocalizing the electronic density, such as:

$$
I^{-}+I_{2} \rightarrow\left[I_{3}\right]^{-}
$$

In the case of the iodinated oil the fixation of the molecular iodine takes place to the double bond with the formation of clathrate type compounds, without breaking the double bond from the unsaturated acids molecules:

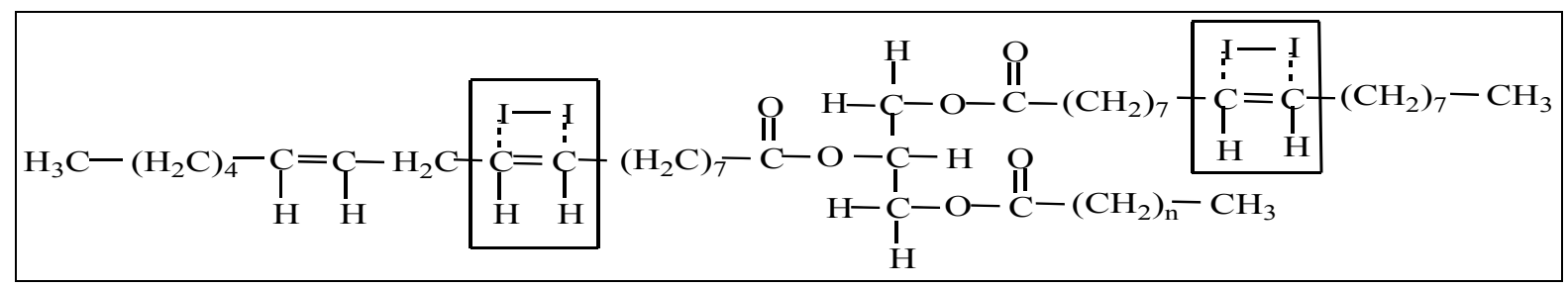

This fact was established by expansion of absorption maximums corresponding to fatty acids double bonds (figure 4).

\section{Sunflower oil}

\section{A}

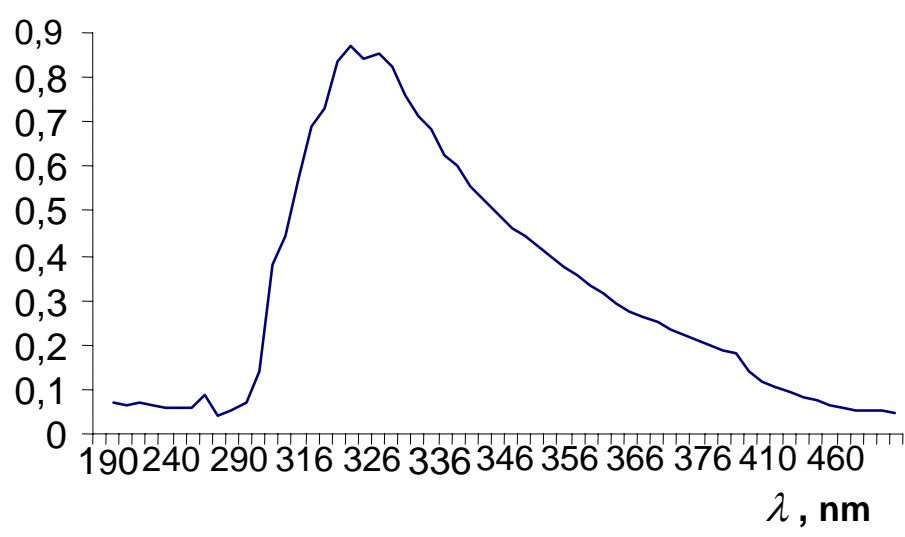

lodinated sunflower oil

A

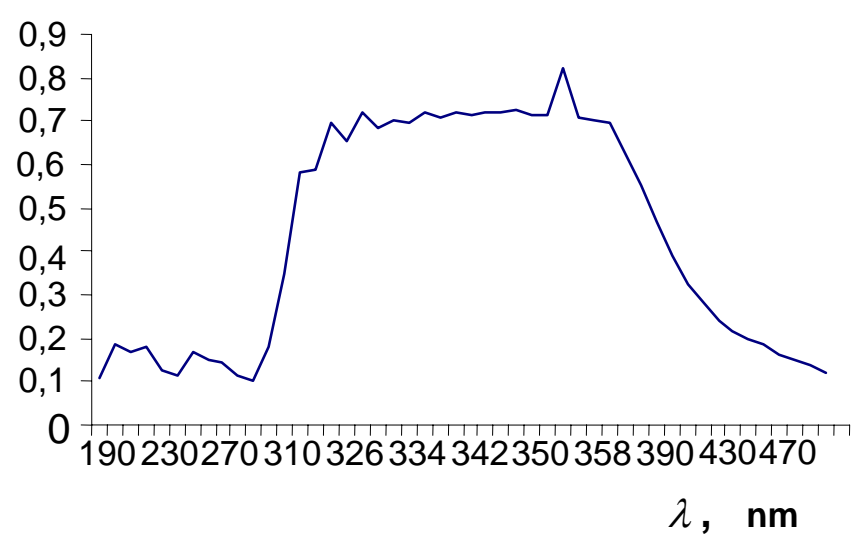

Figure 4. The sunflower and iodinated sunflower oil's absorption spectrum 
In the compounds which form the delocalization of the double bond takes place with the displacement of the electronic density to the iodine molecule, this being more electronegative, which ensures the stability of the formed cycle.

\section{CONCLUSIONS}

It was established that the iodination of the sunflower oil may be considered as a admissible method, which allows the incorporation of a considerable amount of iodine $(1-100 \mu \mathrm{g} / \mathrm{ml})$ without modifying the physical-chemical properties of the product. Physical-chemical indices of the iodinated oil are within the admissible standards for the above-mentioned product.

In the case of the iodination of the oil the addition of the iodine does not take place, but the fixation of molecular iodine to the double bond is performed with the formation of the clathrate type compounds, without the breakage of the double bond from the unsaturated fatty acids molecules. In the formed compounds, the delocalization of the double bond is performed with the displacement of the electronic density to the iodine molecule, this being more electronegative, which ensures the stability of the formed cycle. This allows the efficient incorporation of the molecular iodine in a large range of concentrations $(1-100 \mu \mathrm{g} / \mathrm{ml})$ without a sensible modification of the physical-chemical properties of the product.

These studies indicate that lipids present an important vehicle for the fortification with iodine. Eradication of the iodine deficiency may be realized not only by injection of the iodinated oil, but also by its use as an ingredient for the formulation of different food compositions. This method, complementary with the iodinated salt, would allow the increase of the efficiency of the prophylactic undertaken measures, because is based on the use of vegetal material sunflower oil; it is cost-efficient and does not require substantial investments.

\section{EXPERIMENTAL}

In this study, double rafinated and deodorized oil was used (purchased from local stores), STAS - 18848-73. To obtain the iodinated oil, in one liter of oil $1 \mathrm{~g}$ of chemically pure, crystalline iodine $\left(\mathrm{I}_{2}\right)$ was administrated, STAS 4159- 79 [17]. The iodinated oil had a deep brown color, due to the presence of the free iodine. The oil with the total iodine content $1000 \mu \mathrm{g} / \mathrm{ml}$, was diluted $(1: 100)$, obtaining a product with a the iodine content of $10 \mu \mathrm{g} / \mathrm{ml}$. Diluting $(1: 10)$ the oil sample with $1 \mu \mathrm{g} / \mathrm{ml}$ was obtained. After the establishment of the equilibrium, iodinated oils were used as samples for the present study.

All the measurements were made according to the standard methods and standards STAS - 1129-93 [7,8]. Iodinated oil was analyzed dynamically for three months. The quality indices for oils were determined (physicochemical indices) $[18,19]$ :

- Refraction indices $\left(\mathrm{n}_{\mathrm{d}}^{40}\right)$ - allows the determination of the unsaturation degree of the oil;

- Iodine indices(II) - allows the determination of the global unsaturation of the lipids;

- Saponification indices (IS) - indicates the average molecular mass of the fatty acids;

- Titrable acidity (TA) - and free fatty acids (FFA) - indicates the hydrolytic oxidation degree;

- $\quad$ Peroxide indices (PI) - indicates the degree of the oxidation.

The analysis of the fatty acids in the samples with iodinated oil was performed by gas chromatography with flame ionization detector, using gas chromatograph (helium) HPCHEM 1 FID1 A, equipped with a database and a auto sampler. Fatty acids were separated depending on the length of the chain and depending on the nonsaturation degree. Parameters: start temperature $55^{\circ} \mathrm{C}$; temperature at the loop of the column and the transfer line $110^{\circ} \mathrm{C}$; ventilation $10 \mathrm{sec}$; injection $1.0 \mathrm{~min}, 1 \mu \mathrm{l}$. The temperature of the injector $-180^{\circ} \mathrm{C}$ and the components of the eluent were detected using a flame ionization detector at $250^{\circ} \mathrm{C}$. The concentrations were determined from the area of the pick using the standard curve of the authentic oil and the database.

\section{REFERENCES}

[1] Broussolle C.J., Orgiazzi P.J. Les syndromes des carences iodée. Cahiers nutritionels et diétetiques, 1995.

[2] www.iccidd.org

[3] Alimentaţia şi starea nutrițională a populaţiei din Republica Moldova. Constatări şi recomandări, UNICEF, Biroul pentru Republica Moldova, 2000.

[4] Alimentaţia şi nutriţia umană în Republica Moldova. Constatări şi recomandări UNICEF, Biroul pentru Moldova, 2002.

[5] Studiu national de nutritie, Republica Moldova, Raport final, 1996.

[6] Jaffiol C., J.C. Manderschield, F. De Boisvilloliers Carences nutritionnelles en iode, Cahiers nutritionnel et diét, 1995

[7] Elimination of Iodine Deficiency Disordes in Central end Easten Europe // Proccedings of a Conference heldin Munich, Germany, 1997 WHO/UNICEF/ICCIDD, 1998, 168 pag.

[8] Hotărâre despre Programul Național de eradicare a maladiilor iododeficitare până în anul 2004. Monitorul official al RM, 12.03.1998. 
[9] Delong R. Neurological isorders $t$ in iodine deficiency isorders. In: The prevention and control of iodine deficiency isorders. Hetzel B.S., Dunn J.T., Stanbury J.B. (eds). Elsevier, Amsterdam, 1987, p.49.

[10] Hetzel B.S., Potter B.J., Durberg E.M. The iodine deficiency isorders : Nature, pathogenesis and epidemiology. World Rev. Nutr. Diet., 1990, 62.59-119.

[11] Malone J.K. Consequences of iodine fall out: dosimetric and radiobiological considerations. In: Iodine deficiency in Europe. A continuing concern. Delange F., Dunn J.T., Glinoër D. (eds). Plenum Press,New-York, 1993, pp.229-235.

[12] Broussolle C., Orgiazzi J. Les syndromes de carence iodée. Cah. Nutr.Diét., 1995, 30, 300-305.

[13] Delange F, The disordes induced by iodine deficiency, Thyroid 1994

[14] Merke F. Geochemistry and the iodine cycle. In: „Iconography of endemic goiter and cretinism”. Huber Publ., Bern Stuttgart-Vienne, 1994, pp.10-11.

[15] Merke F. The distribution of endemic goiter and ice age. In: „Iconography of endemic

[16] goiter and cretinism”. Huber Publ., Bern Stuttgart-Vienne, 1994, pp.29-45.

[17] Correa, H. A cost-benefit study of iodine supplementation programs for the prevention of endemic goiter and cretinism. In Endemic Goiter and Endemic Cretinism. ICCIDD 1980.

[18] STAS - 1129 - 9.3 Ulei de floarea soarelui. Condiții tehnice.

[19] Арутюнян Н.С. Лабораторный практикум по технологии переработки жиров. Москва ВО Агропромиздат, 1991.

[20] Ciobanu D. Chimia produselor alimentare-investigații analitice. Tehnica-INFO, Chişinău 2002

[21] Karlreskind Manuel des corps gras, Vol.1,2, Technique et documentation, Lavoisier, 1992. 